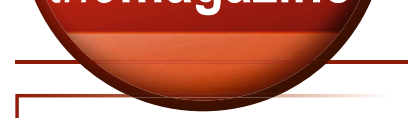

\section{Other Meetings} of Note

Electrometallurgy

Symposium of the XXVIII

International Mineral

Processing Congress

September 11-15, 2016

Quebec City, Canada

8th International Congress and Exhibition Non-Ferrous

Metals and Minerals

September 13-16, 2016

Krasnoyarsk, Russia

Materials Science and

Engineering (MSE 2016)

September 27-29, 2016

Darmstadt, Germany

Arctic Technology

Conference (ATC) 2016

October 24-26, 2016

St. John's, Newfoundland

and Labrador, Canada

European Metallurgical

Conference (EMC) 2017

June 25-28, 2017

Leipzig, Germany

18th International

Conference on

Environmental Degradation

of Materials in Nuclear

Power Systems - Water

Reactors

August 13-17, 2017

Portland, Oregon, USA

2017 Liquid Metal

Processing \& Casting

Conference (LMPC 2017)

September 10-13, 2017

Philadelphia, Pennsylvania, USA

\section{Euromat 2017}

September 17-22, 2017

Thessaloniki, Greece

View all upcoming meetings online at www.tms.org/meetings.

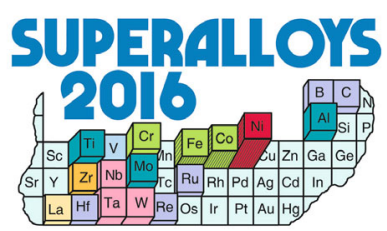

September 11-15, 2016

Seven Springs Mountain Resort

Seven Springs, Pennsylvania, USA www.tms.org/Superalloys 2016

- Superalloys 2016 highlights the benefits of collaborative programs among researchers, producers, and users to bring about tangible improvements in superalloy technology.

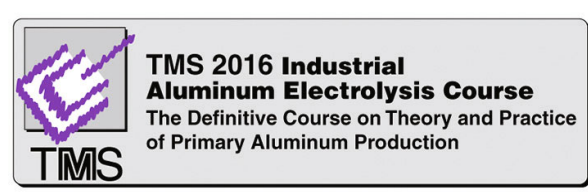

September 19-23, 2016

Nanshan Aluminum Company Longkou City, Shandong Province, China

Register Today:

www.tms.org/IAE2016

- Learn the latest techniques from seven industry experts in a small group setting, allowing for a more interactive course.

- A plant tour at Nanshan Aluminum Company is included in the course registration fee.

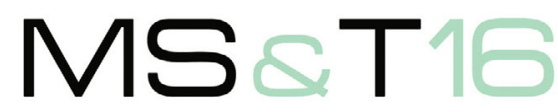

MATERIALS SCIENCE \& TECHNOLOGY

October 23-27, 2016

\section{Salt Palace Convention Center}

Salt Lake City, Utah, USA

Discount Registration Deadline: September 23, 2016 www.matscitech.org

- On Monday, October 24, the six winners of the 2015 Materials Science and Engineering Data Challenge will present their research and findings at the Materials Genome Initiative/ Materials Today - Data Grand Challenge symposium.

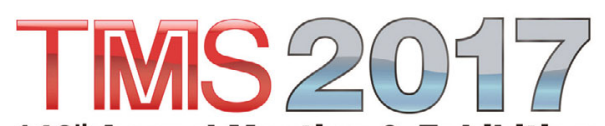

$146^{\text {th }}$ Annual Meeting \& Exhibition

February 26-March 2, 2017

San Diego Convention Center and

Marriott Marquis \& Marina

San Diego, California, USA

Registration Opens Soon!

www.tms.org/TMS2017

- Register your team for the 2017

TMS Bladesmithing Competition by November 10, 2016. For updated judging rubrics, contest rules and requirements, and information on the TMS Wadsworth-Sherby Bladesmithing Grand Prize, visit www.tms.org /Bladesmithing2017.

- Plan ahead for your annual meeting travel and begin the visa application process now. Visit the TMS2017 website today to request an official visa invitation letter.

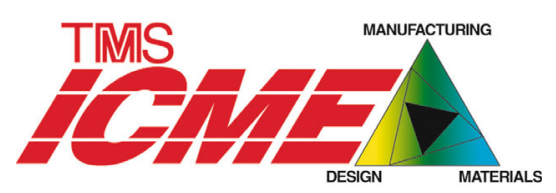

May 21-25, 2017

Marriott Ann Arbor Ypsilanti at Eagle Crest

Ypsilanti, Michigan, USA

Abstract Deadline:

September 30, 2016

www.tms.org/ICME2017

- Attendees of this congress will gain insights on recent advances, new challenges, and the roadmap for overcoming them, giving attendees the opportunity to discuss and influence actual trends in the field.

- Presentations and discussions wil be centered on ICME-related topics, including but not limited to: ICME implementation strategies; verification, validation, and uncertainty quantification issues; and individual computational methods utilized in an ICME approach. 